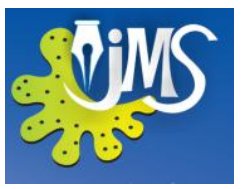

\title{
Comparative Nutritional Evaluation of Three Dried Krill Products Commercially Available in Sri Lanka
}

\author{
${ }^{1}$ Akila Abeywickrama and ${ }^{2}$ Manel Attygalle \\ Department of Zoology \\ University of Sri Jayewardenepura, Sri Lanka
}

\begin{abstract}
In the recent past krill (Sinhala: kooni) has been widely considered for its nutritional value. However almost all the pastnutritional studies on krill have been based on temperate species. Literature related to biochemical composition of tropical species are few. In Sri Lanka no work has been reported on krill. Therefore in the present study, it was aimed to investigate the proximate composition, fatty acid profiles and mineral contents of three dried krill varieties commercially available in Sri Lanka. They included a sun-dried Sri Lankan krill product, a boiled and sundried krill variety imported from Indonesia and a freeze-dried variety imported from India. Based on the observable characteristics, these products most probably belong to the genera Stylocheironand/or Nematoscelis. Crude protein contributed upto54.6 - 71.6\% of the dry matter. Crude fat content varied between $4.5-9.2 \%$ of the dry weight. The ash content was found to range from 22.0 - 40.7\%on dry weight basis. GC/MS analysis of fatty acids revealed higher levels of polyunsaturated fatty acids (43.1 - 53.1\%) for the three krill varieties. Predominating $n$-3 PUFAs fatty acids were eicosapenteinoic acid (EPA, C 20:5) and docosahexaenoic acid (DHA, C22:6). Linoleic (C18:2 n-6) and arachidonic (C20:4 n-6) acids were present as main n-6 PUFAs.Palmitic acid (C16:0) and palmitoleic acid (C16:1 n-7) were the main saturated and monounsaturated fatty acids, respectively. The calculated atherogenic and thrombogenic index values varied between $0.80-2.49$ and $0.17-0.61$ respectively. The mineral element analysis revealed values which ranged from $361.0-483.6 \mathrm{mg} / 100 \mathrm{~g}, 522.3-684.3 \mathrm{mg} / 100 \mathrm{~g}$, 90.5 - $164.8 \mathrm{mg} / 100 \mathrm{~g}$ and 503.8 - $776.0 \mathrm{mg} / \mathrm{l00g}$, for $\mathrm{Na}, \mathrm{Mg}, \mathrm{K}$ and $\mathrm{Ca}$, respectively. Fe (3.5 - 6.5 $\mathrm{mg} / 100 \mathrm{~g})$ and $\mathrm{Zn}(4.1-10.9 \mathrm{mg} / 100 \mathrm{~g})$ were detected as the major trace elements. Fluoride contents recorded in this study $(23.2-63 \mathrm{ppm} w / w)$ were much lower than those reported for krill in earlier studies. Overall, this study demonstrated that dried krill has promising nutritional value, due to its favourable biochemical composition, and deserve further exploitation to increase utilization.
\end{abstract}

KYWORDS: Krill, proximate composition, fatty acid profile, mineral composition, fluoride level 


\section{INTRODUCTION}

Krill are small shrimp-like crustaceans belonging to the order Euphausiacea (Chen, Tou \& Jaczynski, 2009). They are exclusively marine and typically aggregate in massive swarms. This aggregatory behavior has made them attractive for commercial fisheries (Nicol \& Endo, 1997). Antarctic krill (Euphausiasuperba) is the major species concerned in krill fishery and is mainly operated in the Southern ocean (Nicol, Foster \& Kawaguchi, 2012). In Sri Lanka, krill fishery is carried out at minor scale. Dried fish/crustacean products, such as dried fish/sprats, dried shrimps and dried krill are favourite delicacies among Sri Lankan people. During the past decades a trend has been built develop a variety of new products using krill (Nicol, Foster \& Kawaguchi, 2012). Probably this trend was created due to the emerging evidence related to its nutritional significance. Krill has received considerable attention regarding its nutritional significance in recent times and is suggested as a good alternative source of important nutrients. A total of 812 krill-related patents have been reported during the period from 1976-2009 (Nicol, Foster \&Kawaguchi, 2012; Foster, Nicol \& Kawaguchi, 2011). Krill products currently available for human consumption include whole frozen or dried krill, frozen tail meat and processed products such as minces, pastes etc. (Nicol \& Endo, 1997; Boopendranath, 2013). Also there is growing interest in the pharmaceutical and medical applications of compounds derived from krill such as chitin, chitosan and krill enzymes such as, proteases and phospholipases (Nicol \& Endo, 1997; Tou, Jaczynski \& Chen, 2007; Gascon \& Werner, 2005). Chitin and Chitosan have serum cholesterol lowering functions, whereas krill enzymes are used in wound healing and treating ulcers (Tou, Jaczynski \& Chen, 2007; Gascon \& Werner, 2005). In addition, human studies have found numerous health benefits related to omega- 3 fatty acids and antioxidants present in krill oil (Tou, Jaczynski \& Chen, 2007; Tandy et al., 2009; Yoshitomi \& Yamaguchi, 2007). Krill oil has been found to lower the level of serum Low Density Lipoprotein (LDL), total cholesterol and triglycerides and increase the level of High Density Lipoprotein (HDL) (Bunea, Farrah \& Deutsch, 2004). In the same study, at lower or equal doses, krill oil was found to be more effective than fish oil for the reduction of LDL and triglyceride levels. Krill oil is also reported to have beneficial effects on serum lipids as it increases plasma EPA and DHA significantly, resembling a comparable dietary source to fish oil (Ulvenet al., 2010). Past studies on the nutritional composition of krill have been conducted on Antarctic and temperate species. Despite certain studies carried out on the distribution and abundance of euphausiids, literature related to biochemical composition of species in tropical waters are meager. The present study is aimed at investigating proximate composition, fatty acid profile and mineral contents of three dried krill varieties commonly vailable in the Sri Lankan market, as no studies have been reported on krill in Sri Lanka. The varieties studied included local sundried product, boiled and sun-dried Indonesian product and freeze-dried Indian product. Identification of species was difficult as only a few characteristics were observable. According to the observable characteristics, all three krill varieties may probably come from the same one or two genus/genera; Stylocheiron and Nematoscelis. The present study will be the first of its kind to explore the nutritional status of dried krill varieties in Sri Lanka. 


\section{MATERIALS AND METHODS}

The selected three dried krill products (local sun-dried product, boiled and sun-dried Indonesian product and freeze-dried Indian product) available in the market in Sri Lanka were purchased from Pettah dry fish market and Supermarkets. Any other dry fish/crustacean parts mixed with krill samples were removed to make sure that the samples contained only krill. The cleaned samples were homogenized and stored in air-sealed bags until analysis.

The moisture content was determined using the oven drying method described in AOAC, 2000(AOAC, 2000). The method is based on the drying of food sample under controlled temperature $\left(105^{\circ} \mathrm{C}\right)$ for about $3-4 \mathrm{~h}$ until a constant weight is obtained.

Kjeldahl method was used to determine the crude protein content of the samples (James, 1999). The protein content was calculated by multiplying the $\mathrm{N}$ content from 6.25. Acid hydrolysis method (AOAC, 2000) was used to determine the total fat content of the samples. Fat was extracted using Bligh and Dyer method (Bligh \& Dyer, 1959) to prepare fatty acid methyl esters (FAME) (Anon, n.d.). The prepared FAME was analyzed using gas chromatography/mass spectrometry (GC/MS). The temperature of the injector and the detector was $250^{\circ} \mathrm{C}$ and $270^{\circ} \mathrm{C}$.

From the data on the fatty acid composition, the following indexes were calculated.

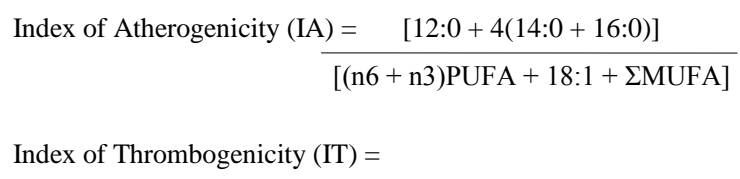

$(14: 0+16: 0+18: 0)$

$[(0.5 \times \overline{18: 1)+0.5(\Sigma M U F A)+0.5(\text { n6PUFA })+3(\text { n3PUFA })}+($ n3PUFA $/$ n6PUFA)]

The total ash content of each sample was measured using Pearson's method (Ronald \& Ronald, 1991). This method involves oxidation of all organic matter by incineration in a furnace at a specified temperature $\left(550{ }^{\circ} \mathrm{C}\right)$ for about $5 \mathrm{~h}$.

Mineral contents were determined using atomic absorption spectrophotometry (AOAC, 2000). Total fluoride content was measured using anion-selective electrode (Anon, 2006).

\section{STATISTICAL ANALYSIS}

All statistical analyzes were conducted using MINITAB program, version 14. The results were analyzed by analyzis of variance (One-way ANOVA). Two-sample t-test was also used, where necessary. All data were tested for normality before conducting ANOVA. Tukey's multiple range tests were used to determine statistical significance at $P<0.05$.

\section{RESULTS}

\subsection{Proximate Composition}

The results obtained for proximate composition of each variety are furnished in Table 1. Sun-dried Sri Lankan product had the lowest moisture content $(24.2 \%)$, followed by Indian krill variety (43.0\%) and boiled Indonesian variety (49.3\%) respectively. Compared to other two varieties, the mean percentage of crudeprotein $(71.6 \%)$ and fat $(9.2 \%)$ contents based on dry basis were found to be significantly high in the Sri Lankan krill variety. The ash content was highest in dried Indian krill variety which has an average of $40.7 \%$ on dry basis. 
Table 1 : Proximate Composition (g/100g dry matter) of Dried Krill Varieties

\begin{tabular}{lccc}
\hline Component & $\begin{array}{l}\text { Sun-dried } \\
\text { variety (Sri Lanka) }\end{array}$ & Boiled variety(Indonesia) & $\begin{array}{l}\text { Freeze-dried variety } \\
\text { (India) }\end{array}$ \\
\hline Moisture & $(24.2 \pm 1.2)^{\mathrm{a}}$ & $(49.3 \pm 0.7)^{\mathrm{b}}$ & $(43.0 \pm 1.3)^{\mathrm{c}}$ \\
Protein & $71.6 \pm 1.1^{\mathrm{b}}(51.6 \pm 2.8)$ & $57.4 \pm 1.3^{\mathrm{c}}(26.3 \pm 1.4)$ & $54.6 \pm 0.5^{\mathrm{a}}(30.0 \pm 0.6)$ \\
Fat & $9.2 \pm 0.5^{\mathrm{c}}(4.4 \pm 0.3)$ & $5.0 \pm 0.1^{\mathrm{a}}(2.3 \pm 0.09)$ & $4.5 \pm 0.6^{\mathrm{a}}(2.5 \pm 0.3)$ \\
Ash & $22.0 \pm 0.6^{\mathrm{a}}(15.9 \pm 0.5)$ & $37.4 \pm 1.1^{\mathrm{b}}(17.1 \pm 0.8)$ & $40.7 \pm 0.3^{\mathrm{c}}(22.3 \pm 0.2)$ \\
\hline
\end{tabular}

Results are given as mean \pm S.D. of ten replicate analyzes. Different superscripts in the same row indicate significant differences $(P<0.05)$. The values in parenthesis indicate proximate composition of the products, as purchased.

\subsection{Fatty Acid Profile}

As shown in Table 2, thirty (30) different fatty acids were recorded in the krill fat. The highest number of fatty acids (25) was recorded in boiled and sun-dried Indonesian krill variety. All three krill varieties; contained relatively high content of polyunsaturated fatty acids $(53.1 \%, 43.1 \%$ and $44.9 \%$ in Sri Lankan, Indonesian and Indian variety, respectively) oversaturated and monounsaturated fatty acids. Eicosapentanoic (C20:5 n-3, EPA) and docosahexanoic (C22:6 n-3, DHA) were the two major PUFAs. The highest EPA and DHA values were detected in Sri Lankan krill variety (16.4\% EPA and 19.3\% DHA). Among n-6 PUFAs, linoleic acid (C18:2 n-6) was the most prominent fatty acid, which contributed $6.2 \%$, $2.2 \%$ and $13.1 \%$ in Sri Lankan, Indonesian and Indian krill variety, respectively. Arachidonic acid (C20:4 n-6) was also present in significant amounts in all three products $(7.7 \%, 4.1 \%$ and $3.1 \%$ in Sri Lankan, Indonesian and Indian variety, respectively). The principal MUFA present was palmitoleic acid $(7.3 \%, 7.3 \%$ and $8.3 \%$ in Sri Lankan, Indonesian and Indian krill variety, respectively). Among the saturated fatty acids, palmitic (C16:0) acid was the most abundant in all samples $(14.5 \%, 15.1 \%$ and $20.9 \%$ of Sri Lankan, Indonesian and Indian varieties, respectively), followed by stearic acid (C18:0). Both atherogenic index and index of thrombogenicity were highest for Indian variety (2.495 and 0.615, respectively) followed by Sri Lankan and Indonesian variety, consequently. 
Table 2 : Fatty Acid Composition of Dried Krill Varieties (as percentage of total fatty acid methyl esters)

\begin{tabular}{|c|c|c|c|c|}
\hline \multicolumn{2}{|r|}{ Fatty Acids } & \multicolumn{3}{|c|}{ Percentage (\%) of Total Fatty Acids } \\
\hline $\begin{array}{l}\text { Nomenclatu } \\
\text { re }\end{array}$ & Systematic / Trivial Name & $\begin{array}{c}\text { Sri Lankan } \\
\text { Product }\end{array}$ & $\begin{array}{l}\text { Indonesian } \\
\text { Product }\end{array}$ & Indian Product \\
\hline C12:0 & Lauric acid & $0.15 \pm 0.01^{\mathrm{b}}$ & $0.1 \pm 0.01^{\mathrm{c}}$ & $0.6 \pm 0.01^{\mathrm{a}}$ \\
\hline $\mathrm{C} 14: 0$ & Myristic acid & $3.4 \pm 0.03^{\mathrm{c}}$ & $2.1 \pm 0.02^{\mathrm{a}}$ & $5.3 \pm 0.07^{b}$ \\
\hline C15:0 & Pentadecanoic acid & $0.5 \pm 0.01^{\mathrm{a}}$ & $0.1 \pm 0.01^{b}$ & $1.8 \pm 0.01^{\mathrm{c}}$ \\
\hline C16:0 & Palmitic acid & $14.5 \pm 0.03^{b}$ & $15.1 \pm 0.005^{\mathrm{c}}$ & $20.9 \pm 0.03^{\mathrm{a}}$ \\
\hline $\mathrm{C} 17: 0$ & Margaric acid & $1.3 \pm 0.01^{\mathrm{a}}$ & $3.2 \pm 0.05^{\mathrm{b}}$ & ND \\
\hline C18:0 & Stearic acid & $9.1 \pm 0.04^{\mathrm{c}}$ & $6.3 \pm 0.02^{b}$ & $13.5 \pm 0.03^{\mathrm{a}}$ \\
\hline C19:0 & Nonadecanoic acid & $0.5 \pm 0.01^{\mathrm{a}}$ & $0.6 \pm 0.005^{b}$ & ND \\
\hline $\mathrm{C} 20: 0$ & Arachidic acid & $0.6 \pm 0.01^{\mathrm{b}}$ & $1.4 \pm 0.02^{\mathrm{a}}$ & ND \\
\hline C22:0 & Behenic acid & $0.97 \pm 0.02$ & ND & ND \\
\hline C23:0 & Tricosanoic acid & ND & $0.2 \pm 0.01$ & ND \\
\hline \multicolumn{2}{|r|}{ Total SFA } & $31.2 \pm 0.1^{b}$ & $29.2 \pm 0.1^{\mathrm{a}}$ & $42.3 \pm 0.1^{c}$ \\
\hline C16:1 (n-7) & Palmitoleic acid & $7.3 \pm 0.03^{\mathrm{a}}$ & $7.3 \pm 0.02^{\mathrm{a}}$ & $8.3 \pm 0.01^{b}$ \\
\hline C18:1 (n-9) & Oleic acid & $5.6 \pm 0.02^{\mathrm{a}}$ & $14.6 \pm 0.02^{b}$ & ND \\
\hline C20:1 (n-7) & Paullinic acid & $0.6 \pm 0.02^{\mathrm{a}}$ & $2.2 \pm 0.01^{\mathrm{b}}$ & ND \\
\hline C20:1 (n-9) & Gondoic acid & $0.3 \pm 0.01$ & ND & ND \\
\hline C22:1 (n-9) & Erucic acid & ND & $0.8 \pm 0.01$ & ND \\
\hline C24:1 (n-9) & Nervonic acid & $0.5 \pm 0.02^{\mathrm{a}}$ & $1.8 \pm 0.02^{b}$ & ND \\
\hline \multicolumn{2}{|r|}{ Total MUFA } & $14.4 \pm 0.01^{\mathrm{a}}$ & $26.9 \pm 0.1^{b}$ & $8.3 \pm 0.02^{c}$ \\
\hline C16:2 & Hexadecadienoic & ND & ND & $11.0 \pm 0.02$ \\
\hline C18:2 (n-6) & Linoleic acid & $6.2 \pm 0.02^{\mathrm{a}}$ & $2.2 \pm 0.03^{\mathrm{b}}$ & $13.1 \pm 0.02^{\mathrm{c}}$ \\
\hline C20:2 (n-6) & Eicosadienoic acid & ND & $0.6 \pm 0.02$ & ND \\
\hline C16:3 (n-3) & Hexadecatrienoic acid (HTA) & ND & $0.1 \pm 0.005$ & ND \\
\hline C18:3 (n-6) & $\gamma-$ linolenic acid (GLA) & $0.8 \pm 0.02^{\mathrm{a}}$ & $0.2 \pm 0.01^{\mathrm{b}}$ & Trace \\
\hline C20:3 (n-6) & $\begin{array}{l}\text { Dihomo-gamma-linolenic acid } \\
\text { (DGLA) }\end{array}$ & $0.2 \pm 0.02^{b}$ & $0.3 \pm 0.01^{\mathrm{a}}$ & ND \\
\hline C18:4 (n-3) & Stearidonic acid (SDA) & ND & $1.9 \pm 0.04$ & ND \\
\hline C20:4 (n-6) & Arachidonic (AA) & $7.7 \pm 0.06^{\mathrm{a}}$ & $4.1 \pm 0.01^{b}$ & $3.7 \pm 0.05^{\mathrm{c}}$ \\
\hline C20:4 (n-3) & Eicosatetraenoic acid (ETA) & $0.4 \pm 0.01^{\mathrm{a}}$ & $0.8 \pm 0.01^{\mathrm{b}}$ & ND \\
\hline$C 20: 5(n-3)$ & Eicosapentaenoic acid (EPA) & $16.4 \pm 0.08^{b}$ & $12.8 \pm 0.02^{\mathrm{c}}$ & $10.3 \pm 0.01^{\mathrm{a}}$ \\
\hline C21:5 (n-3) & $\begin{array}{l}\text { Heneicosapentaenoic acid } \\
\text { (HPA) }\end{array}$ & $0.6 \pm 0.01$ & ND & ND \\
\hline $\mathrm{C} 22: 5(\mathrm{n}-3)$ & $\begin{array}{l}\text { Docosapentaenoic acid } \\
\text { (Clupanodonic acid) }\end{array}$ & ND & $1.3 \pm 0.01^{\mathrm{a}}$ & $1.6 \pm 0.02^{b}$ \\
\hline C22:5 (n-6) & $\begin{array}{l}\text { Docosapentaenoic acid } \\
\text { (Osbond acid) }\end{array}$ & $0.9 \pm 0.01$ & ND & ND \\
\hline $\mathrm{C} 22: 6(n-3)$ & Docosahexaenoic acid (DHA) & $19.3 \pm 0.02^{\mathrm{a}}$ & $18.9 \pm 0.03^{b}$ & $5.0 \pm 0.1^{\mathrm{c}}$ \\
\hline \multicolumn{2}{|r|}{ Total PUFA } & $53.1 \pm 0.1^{\mathrm{a}}$ & $43.1 \pm 0.5^{b}$ & $44.9 \pm 0.03^{c}$ \\
\hline \multicolumn{2}{|r|}{ PUFA/SFA } & $1.6 \pm 0.007^{b}$ & $1.4 \pm 0.01^{\mathrm{c}}$ & $1.0 \pm 0.004^{\mathrm{a}}$ \\
\hline \multicolumn{2}{|r|}{ Total n-3 PUFA } & $36.9 \pm 0.1^{\mathrm{c}}$ & $36.1 \pm 0^{0.08}$ & $17.0 \pm 0.1^{b}$ \\
\hline \multicolumn{2}{|r|}{ Total n-6 PUFA } & $16.0 \pm 0.07^{\mathrm{a}}$ & $7.5 \pm 0.04^{b}$ & $16.9 \pm 0.04^{c}$ \\
\hline \multicolumn{2}{|r|}{ n-6/n-3 } & $0.4 \pm 0.003^{\mathrm{a}}$ & $0.2 \pm 0.001^{b}$ & $0.9 \pm 0.009^{c}$ \\
\hline \multicolumn{2}{|r|}{ EPA/DHA } & $0.8 \pm 0.004^{b}$ & $0.6 \pm 0.001^{\mathrm{a}}$ & $2.0 \pm 0.05^{\mathrm{c}}$ \\
\hline \multicolumn{2}{|c|}{ Index of Atherogenicity (IA) } & $0.985 \pm 0.002^{\mathrm{a}}$ & $0.808 \pm 0.002^{b}$ & $2.495 \pm 0.013^{c}$ \\
\hline \multicolumn{2}{|c|}{ Index of Thrombogenicity (IT) } & $0.206 \pm 0.0005^{b}$ & $0.170 \pm 0.0005^{c}$ & $0.615 \pm 0.002^{\mathrm{a}}$ \\
\hline
\end{tabular}

Results are given as mean \pm S.D. of three replicate analyzes. Different superscripts in the same row indicate significant differences $(\mathrm{p}<0.05)$. ND - Not Detected 


\subsection{Mineral Composition}

Table 3 summarizes the contents of $(164.8 \mathrm{mg} / 100 \mathrm{~g})$ and $\mathrm{Ca}$ content (776.0 macro and trace minerals recorded for dried krill varieties. Among macro-elements the $\mathrm{mg} / 100 \mathrm{~g})$. Overall, all three krill products were highly rich in macro-minerals. Fe $(3.5-6.5$ highest $\mathrm{Na}$ and $\mathrm{Mg}$ concentrations (483.6 and $684.3 \mathrm{mg} / 100 \mathrm{~g}$ ) were reported for Sri Lankan and Indonesian krill variety, respectively. The Indian krill variety accounted for the highest $\mathrm{K}$ $\mathrm{mg} / 100 \mathrm{~g})$ and $\mathrm{Zn}(4.1$ - $10.9 \mathrm{mg} / 100 \mathrm{~g})$ were reported as the most prominent trace elements. $\mathrm{Ni}$ was found in low quantities $(0.04-0.9$ $\mathrm{mg} / 100 \mathrm{~g}$ ) in all samples.

Table 3 : Mineral Profile of Dried Krill Varieties (mg/100g dry matter)

\begin{tabular}{llll}
\hline Mineral Element & $\begin{array}{l}\text { Sun-dried } \\
\text { variety (Sri Lanka) }\end{array}$ & $\begin{array}{l}\text { Boiled } \\
\text { variety (Indonesia) }\end{array}$ & $\begin{array}{l}\text { Freeze-dried variety } \\
\text { (India) }\end{array}$ \\
\hline & Macro-elements & & \\
$\mathrm{Na}$ & $483.6 \pm 5.3^{\mathrm{a}}$ & $361.0 \pm 2.6^{\mathrm{b}}$ & $410.1 \pm 3.6^{\mathrm{c}}$ \\
$\mathrm{K}$ & $90.5 \pm 5.4^{\mathrm{b}}$ & $119.3 \pm 2.8^{\mathrm{c}}$ & $164.8 \pm 3.5^{\mathrm{a}}$ \\
$\mathrm{Mg}$ & $522.3 \pm 2.2^{\mathrm{c}}$ & $684.3 \pm 4.4^{\mathrm{a}}$ & $634.3 \pm 6.3^{\mathrm{b}}$ \\
$\mathrm{Ca}$ & $503.8 \pm 2.1^{\mathrm{a}}$ & $716.8 \pm 3.6^{\mathrm{c}}$ & $776.0 \pm 4.6^{\mathrm{b}}$
\end{tabular}

\section{Trace elements}

\begin{tabular}{|c|c|c|c|}
\hline Total Fluoride (ppm) & $57.0 \pm 2.1^{\mathrm{b}}$ & $40.8 \pm 2.3^{\mathrm{c}}$ & $63.0 \pm 2.1^{\mathrm{a}}$ \\
\hline $\mathrm{Mn}$ & $1.1 \pm 0.01^{\mathrm{a}}$ & $1.0 \pm 0.07^{\mathrm{b}}$ & $1.3 \pm 0.01^{\mathrm{c}}$ \\
\hline $\mathrm{Fe}$ & $6.5 \pm 0.007^{\mathrm{c}}$ & $3.5 \pm 0.09^{b}$ & $5.7 \pm 0.02^{\mathrm{a}}$ \\
\hline $\mathrm{Zn}$ & $5.1 \pm 0.02^{\mathrm{a}}$ & $10.9 \pm 0.7^{\mathrm{b}}$ & $4.1 \pm 0.03^{c}$ \\
\hline $\mathrm{Cu}$ & $1.6 \pm 0.01^{\mathrm{b}}$ & $1.3 \pm 0.01^{\mathrm{c}}$ & $0.8 \pm 0.008^{a}$ \\
\hline $\mathrm{Ni}$ & $0.04 \pm 0.008^{\mathrm{a}}$ & $0.9 \pm 0.008^{\mathrm{b}}$ & $0.9 \pm 0.01^{\mathrm{b}}$ \\
\hline
\end{tabular}

Results are given as mean \pm S.D. of six replicate analyzes. Different superscripts in the same row indicate significant differences $(\mathrm{p}<0.05)$. 


\section{DISCUSSION}

Among nutrition research on shellfish, krill have gained special attention recently, due to their evident nutritive value (Tou, Jaczynski $\&$ Chen, 2007). Variations observed in the proximate composition between the three krill varieties during the present study, cannot be attributed to a particular reason. Alarge number of biological (species, sex, maturation stage, size, age, diet) and ecological (season, food availability and etc.) factors are known to have a clear effect on proximate composition of crustaceans (Rosa \& Nunes, 2003; Dinakaran, Soundarapandian \& Chandra, 2009;Pugalopezet al., 2013). Processing method also can affect the proximate composition. Significant differences in the proximate composition between sun-dried and boiled Penaeusnotialis have been recorded in literature (Bello, 2013). A similar variation was observed for the different processing and drying methods employed in the present study.

The different moisture contents recorded for the three dried krill varieties in the present study indicate that they are dried to varying degrees. Sun-dried Sri Lankan variety was the highest dried, while boiled Indonesian variety is the least dried. The high moisture content observed in Indian variety may be due to the high rehydration tendency of freeze-dried foods, because of their porous nature. The crudeprotein contents of three krill varieties (71.6\%, 57.4\% and 54.6\% dry weight for Sri Lankan, Indonesian and Indian variety, respectively) are compatible with the study by Dinakaran, Soundarapandian \& Chandra, 2009 who found protein in the range of $57-61 \%$ on a dry weight basis in the muscle tissues of the prawn Macrobrachiumidae and stated that, protein is the main constituent of crustaceans.
The dried whole krill samples in this study constituted the muscle tissue as well as the exoskeleton. Another study comparing the chemical composition and amino acid profile of the muscle tissue and exoskeleton of Macrobrachiumvollenhovenii, concluded that they were good sources of protein and amino acids which could be used for feed formulation and consumed by humans. The exoskeleton of arthropods is made up of chitin together with various proteins and impregnated with various minerals. Shrimp waste protein digestibility has been found to be low because of the chitin compounds (Ehigiator \& Oterai, 2012).

According to the recommended dietary allowances (RDA) for Sri Lankans (Anon, $2012)$, consumption of a serving $(\sim 20 \mathrm{~g})$ of dried whole krill, (which contain $26-51 \%$ protein as purchased), can help towards achieving the daily need of protein of an adult (53 g/day and $44 \mathrm{~g} /$ day for a man and woman respectively). Low fat content $(<10 \%)$ reported for dried krill can be considered as an indication of their resistance to oxidation (Bello, 2013). High ash content (range from $22-40 \%$ dry weight) obtained in the present study revealed the richness of mineral composition in krill.

The higher relative content of polyunsaturated fatty acids (PUFA) observed in all dried krill varieties were similar to that pattern observed previously (Shujing, Qixing \& Wenshui, 2012). The ratio between PUFA and SFA reported for three krill varieties (1.6, 1.4 and 1.0 for Sri Lankan, Indonesian and Indian krill variety, respectively) were fairly compatible with those of previous studies, which recorded values in the range of $0.5-2.0$ including seasonal variations (Shujing, Qixing \& Wenshui, 2012; Juet al., 2009; Mayzaud, Virtue \& Albessard, 1999). Also this finding 
was well within the recommendations of HMSO (1994), which suggests a minimum value of 0.45 for this ratio (HMSO, 1994). Both the current study and literature references (Shujing, Qixing \& Wenshui, 2012; Ju et al., 2009; Mayzaud, Virtue \& Albessard, 1999; Saether, Ellingsen \& Mohr, 1986) showed high levels of EPA and DHA for krill. Ju et al., 2009 have mentioned that DHA is only abundant in temperate krill species. However, it is contrary to the present results. When considering the $\mathrm{n}$ $6 / n-3$ fatty acid ratio, the recommended ratio is somewhat controversial among different sources (Wijendran \& Hayes, 2004). However, it is recommended to have a value of not more than 5 (Moreira et al., 2001). It is desirable to have more $n-3$ fatty acids than $n-6$ fatty acids (Garaffo, 2011). The values obtained for $\mathrm{n}-6 / \mathrm{n}$ 3 ratio, in the present work $(0.4,0.2$ and 0.9 for Sri Lankan, Indonesian and Indian variety, respectively) were able to meet this requirement. Stearic (C18:0), linoleic (C18:2 n6) and arachidonic (C20:4 n-6) acids, which were recorded within ranges of $1.2-2.4 \%, 0.1$ $4.6 \%$ and $0.7-1.8 \%$ in above-mentioned previous studies, showed higher levels in the present study ( $6-13 \%$ stearic, $2-13 \%$ linoleic and $3-7 \%$ arachidonic). These differences may be either due to one or combination of factors that affect the fatty acid composition, including geographical differences compared to other works from other countries. Atherogenic and thrombogenic indices evaluate the effects of saturated and unsaturated fatty acids, and indicate the probability of giving rise to atheroma and thrombus formation like incidences. However, the values obtained for both atherogenic and thrombogenic indices in the present study (except atherogenic index of the dried Indian krill variety) can be considered to be low $(<1.0)$, in agreement with the literature.
In recent years, promising health benefits of dietary fatty acids began to be investigated thoroughly. A higher proportion of total MUFAs and PUFAs than SFAs in the diet was found to reduce low-density lipoproteins (LDL) and increase high-density lipoproteins (HDL) in blood and thereby assist in the removal of triglycerides from the blood stream (KrisEtherton et al., 2000). Also EPA and arachidonicacid (AA) were found to relax blood vessels by inhibiting platelet aggregation (Wijendran \& Hayes, 2004). With these potential benefits attributed to its constituent fatty acids, krill is worth considering for nutritional applications.

There are wide variations in the reported values of macro and trace mineral concentrations in the whole krill and related products, among various sources. When considering macro-elements, the obtained results (range from a minimum value of 90.5 $\mathrm{mg} / 100 \mathrm{~g}$ to a maximum value of $776.0 \mathrm{mg} / 100 \mathrm{~g}$ dry weight) were more or less compatible with the values reported (range from $64.1-2830$ $\mathrm{mg} / 100 \mathrm{~g}$ dry weight) in the literature (Tou, Jaczynski \& Chen, 2007). Trace minerals also exhibited a similar kind of trend (range from $0.04-10.96 \mathrm{mg} / 100 \mathrm{~g}$ dry weight). The present results revealed that krill is a rich source of iron (3.5 - $6.5 \mathrm{mg} / 100 \mathrm{~g}$ dry weight). WHO has stated that, recognizing food sources with a considerable amount of iron is important, since it is the most common nutrient deficiency in the world (WHO, 2001). However, none of the other authors have published fluoride concentrations in whole krill as low as the present work (23-63 ppm). This may be due to geographical and climatic differences in the environments they inhabit. 
In conclusion, the overall comparison among the three experimented krill products revealed that the sun dried local krill variety is higher in nutritional value than the other two products available in the market. In addition, the present investigation demonstrated that variously processed dried krill can serve as an alternative source of high quality protein for human consumption. The lower fat content increases its nutritional value. Dried krill can also function as a good mineral source with major structural and trace minerals for the prevention of bone loss and iron deficiency. The mostly discussed caution involved with krill is their high fluoride content. However toxic level of fluoride was not observed in the present work and that increase its potential value. Fatty acid profile of dried krill proved that, they possess higher amounts of n-3 fatty acids, and hence have more nutritional value in terms of human health. Therefore, dried krill can be suggested as a promising nutritional source which holds numerous health benefits.

\section{REFERENCES}

ANON (N.D.). Method manual for preparation of fatty acid methyl esters. Industrial Technology Institute, Sri Lanka.

ANON (2006). Specification for toothpaste (Second Revision). Sri Lanka Standards Institution.

ANON (2012). Recommended dietary allowances for Sri Lanka. Available at :http://hexagonnutrition.com/rda/rdasrilanka.php [accessed : 16 Jan. 2014].

AOAC (2000). Official Methods of Analysis of Association of Official analytical Chemists international. (2000), $17^{\text {th }}$ ed. AOAC International, Virginia, USA.

BELLO, B.K. (2013). Effect of processing method on the proximate and mineral composition of prawn (Penaeusnotialis). Journal of Global Biosciences, v. 2 pp. 4246.

BLIGH, E.G. \& DYER, W.J. (1959). A rapid method of total lipid extraction and purification. Canadian Journal of Biochemistry and Physiology, v. 37 pp. 911917.

BOOPENDRANATH, M.R. (2013). Antarctic krill - A keystone species of Antarctica. Science India, v. 16 pp. 4-10

BUNEA, R., FARRAH, K. \& DEUTSCH, L. (2004). Evaluation of the effects of neptune krill oil on the clinical course of hyperlipidemia. Alternative Medicine Review, v. 9 pp. 420-428.

CHEN, Y.C., TOU, J.C. \& JACZYNSKI, J. (2009). Amino acid and mineral composition of protein and other components and their recovery yields from whole Antarctic krill (Euphausiasuperba) using isoelectric solubilization/precipitation. Journal of Food Science, v. 74 pp. 31-39.

DINAKARAN, G.K., SOUNDARAPANDIAN, P. \& CHANDRA, S.K. (2009). Proximate composition of edible palaemonid prawn Macrobrachium idea. Current Research Journal of Biological Sciences, v. 1 pp. 7882.

EHIGIATOR, F.A.R. \& OTERAI, E.A. (2012). Chemical composition and amino acid profile of a Caridean prawn (Macrobrachiumvollenhovenii) from Oviariver and tropical periwinkle (Tympanotonusfuscatus) from Benin river, Edo State, Nigeria. International Journal of Research and Reviews in Applied Sciences, v. 11 pp. 162-167.

FOSTER, J., NICOL, S. \& KAWAGUCHI, S. (2011). The use of patent databases to predict trends in the krill fishery. CCAMLR Science. 18, 135-144. 
GARAFFO, M.A. (2011). Fatty acids profile, atherogenic (IA) and thrombogenic (IT) health lipid indices of raw roe of blue fin tuna (Thunnusthynnus L.) and their salted product "bottarga". Food and Nutrition Sciences, v. 2 pp. 736-743.

GASCON, V. \& WERNER, R. (2005). Antarctic krill : A case study on the ecosystem implications of fishing. Lighthouse Foundation, Argentina.

HMSO (1994). Nutritional aspects of cardiovascular disease (report on health and social subjects No. 46). HMSO, London, U.K.

JAMES, C.S. (1999). Analytical Chemistry of Foods. Blackie Academic and Professional, Glasgow, U.K. pp. 64-65.

JU, S. ET AL., (2009). Comparative lipid dynamics of euphausiids from the Antarctic and Northeast Pacific oceans. Marine Biology, 156, 1459-1473.

KRIS-ETHERTON, P.M. ET $A L$., (2000). Beneficial effects of a diet high in monounsaturated fatty acids on risk factors for cardiovascular disease. Nutrition in Clinical Care, v. 3 pp.153-162.

MAYZAUD, P., VIRTUE, P. \& ALBESSARD, E. (1999). Seasonal variations in the lipid and fatty acid composition of the euphausiid Meganyctiphanesnorvegica from the Ligurian sea. Marine Ecology Progress Series, v. 186 pp. 199-210.

PUGA MOREIRA, A.B. ET AL.,(2001). Fatty acids profile and cholesterol contents of three Brazilian Brycon freshwater fishes. Journal of food composition and analysis, v. 14 pp. 565-574.

NICOL, S. \& ENDO Y.(1997). Krill fisheries of the world. Food and Agriculture Organization of the United Nations, Rome.

NICOL, S., FOSTER, J. \& KAWAGUCHI, S.(2012). The fishery for Antarctic krill -
Recent developments. Fish and Fisheries, v. 13 pp. 30-40.

PUGA-LOPEZ, D. ET AL. (2013). Physicochemical, proximate composition, microbiological and sensory analysis of farmed and wild harvested white shrimp Litopenaeusvannamei tissues. Current Research Journal of Biological Sciences, v. 5 pp. $130-135$.

RONALD, S.K. \& RONALD, S. (1991). Pearson's composition and analysis of foods. Longman Group Publisher Limited, UK. 9-38.

ROSA, R. \& NUNES, M.L. (2003). Biochemical composition of deep-sea decapod crustaceans with two different benthic life strategies off the Portuguese south coast. Deep-Sea Research, v. 50 pp. 119-130.

SAETHER, O., ELLINGSEN, T.E. \& MOHR, V. (1986). Lipids of North Antarctic krill. Journal of Lipid Research, v. 27 pp. 274285.

SHUJING, L.I., QIXING, J. \& WENSHUI, X. (2012). Chemical compositions and nutritional quality of muscle and processing by-products of Antarctic krill (Euphausiasuperba). National High Technology Research and Development Program, China.

TANDY, S.ET AL.,(2009). Dietary krill oil supplementation reduces hepatic steatosis, glycemia and hypercholesteromia in high-fat fed mice. Journal of Agricultural and Food Chemistry, DOI:10.1021/jf9016042.

TOU, J.C., JACZYNSKI, J. \& CHEN, Y. (2007). Krill for human consumption : Nutritional value and potential health benefits. Nutrition Reviews, v. 65 pp. 63-77.

ULVEN, S.M. ET AL. (2010). Metabolic effects of krill oil are essentially similar to those of fish oil but at lower dose of EPA and DHA 
in healthy volunteers. Lipids, v. 46 pp. 3746.

WIJENDRAN, V. \& HAYES, K.C. (2004). Dietary n-6 and n-3 fatty acid balance and cardiovascular health. Annual Review of Nutrition, v.24 pp.597-615.

WORLD HEALTH ORGANIZATION (2001). Iron deficiency anemia : Assessment, prevention and control. A guide for program managers. WHO, Geneva.

YOSHITOMI, B. \& YAMAGUCHI, H. (2007). Chemical composition of dried eyeballs from Euphausiasuperba and Euphausiapacifica. Fisheries Science, v. 73 pp. 1186-1194. 